\title{
Prospective Teachers' Attitudes toward Whistle-Blowing According to Type of Intelligence
}

\author{
Asiye Toker Gökçe \\ Kocaeli University, Faculty of Education, \\ Department of Educational Sciences, \\ asi.gokce@kocaeli.edu.tr
}

Doi: 10.5901/mjss.2013.v4n4p11

\begin{abstract}
This study inquires differences of whistle-blowing intentions between first and the last year student teachers through three scenarios in terms of their assumed types of intelligence. Ethical awareness with underlying reasoning of the students was investigated; and possible intentions of the students to whistle-blow were examined. The survey was conducted among 291 university students. While overall ethical awareness of the students with verbal intelligence was higher than the students with mathematical intelligence in one scenario, any difference was found between the $1^{\text {st }}$ and $4^{\text {th }}$ year students. Besides, 1 st year students' intentions for internal, external, and identified reporting are higher than the $4^{\text {th }}$ year ones. Mathematical intelligence did not make any difference between the students' intentions to blow whistle. There is not any intention for examining whistle-blowing it in education and any evidence on the relationship between it and intelligence types in the literature. This paper is expected to contribute the literature.
\end{abstract}

Keywords: Whistle-blowing, ethical evaluation, intelligence, education, prospective teachers.

\section{Introduction}

Whistle-blowing is described as 'the disclosure by organization members of illegal, immoral or illegitimate practices under the control of their employers, to persons or organizations that may be able to effect action'. A whistle-blower releases information deliberately, and employs unconventional methods to make the disclosure. When normal disclosure channels have failed, the whistle-blower may feel compelled to act. A whistle-blower has two dilemmas; a dissent between personal and organizational values, and a dissent between engagements owed to his/her organization and to parties beyond it. Thus moral courage and moral reasoning are two of the most important factors to understanding one's propensity to blow the whistle. Moral reasoning requires the ability to recognize and correctly evaluate any ethical dilemma (Near at al. 1993; Jubb, 1999; Miceli et al. 2001; Liyanarachchi and Newdick, 2009). Although researchers have studied level of moral reasoning by philosophical values (i.e. Liyanarachchi and Newdick, 2009; McDevitt and Van Hise, 2002; Keenan, 2002; Tavakoli et al., 2003; and Near et al. 2004; Reidenback and Robin, 1990; Cohen et al. 1993, 2001; and Cruz et al. 2000), no study seeking a possible relation of thinking styles with moral courage has been seen in the whistle-blowing literature. So this study aims to investigate whistle-blowing intentions of $1^{\text {st }}$ and $4^{\text {th }}$ year student teachers, who are supposed to have verbal and mathematical intelligence, investigating their moral reasoning to blow the whistle. This paper is anticipated to contribute to the whistle-blowing studies attempting to investigate underlying reasons for ethical evaluation, and whistle-blowing intentions of student educators in respect to their thinking styles.

\section{Literature review}

\subsection{Whistle-blowing}

Whistle-blowing is a process of giving information about the acts resulting in harm to third parties. It is a disclosure by organization members of illegal, immoral, or illegitimate practices under the control of their employers, to persons or organizations that may be able to effect action. Although whistle-blowing seems to be a threat to organizational authority structures, it can improve long-term organizational effectiveness when leaders encourage whistle-blowing in their organizations to improve their organization's effectiveness and efficiency. So, organization members, stockholders, and 
society can benefit from the halt of organizational wrongdoings such as fraud, discrimination, or safety violations. From this point, whistle-blowers may suggest solutions to organizational problems (Near \& Miceli, 1985; Miceli et al. 1999). Whistle-blowers are those who sound the alert on, wrongdoings, malpractice, or corruption. A whistle-blower can be a former or current employee of any private or public institution. A whistle-blower believes either that he/she has been ordered to perform some act or he/she has obtained knowledge that the institution is engaged in activities are causing unnecessary harm to third parties or violate human rights (Elliston, 1982; Vinten, 1996; Dawson, 2000; Near et al. 2004). Thus it seems that the most important step for a whistle-blower may be deciding whether the act s/he observed or was ordered is a wrongdoing or not. Near et al. (2004) created taxonomies of wrongdoing in organizations such as waste and discrimination, legal violations mismanagement and sexual harassment, and stealing and safety problems. They claimed that the type of wrongdoing affects whistle blower's intention to blow the whistle. Actually whistle-blowing preliminary requires realizing wrongdoings, and then making decision for blowing whistle comes. So the decision-making process for blowing the whistle is associated with the potential whistle-blower's traits and moral reasoning (Elliston, 1982; Vinten, 1996; Near et al. 2004). Miceli et. al $(1985 ; 2001)$ claim that an individual's perceptions about whistle-blowing are related to the decision to blow the whistle. Besides, individual traits such as positive and negative affectivity and proactive personality affect the evaluation of wrongdoing and whistle-blowing. Furthermore, self-efficacy for whistle-blowing and perceived organizational support affect individuals' responses to wrongdoing. Some researches (Franke et al. 1997; Deshpande, 1997; Dawson, 1997; Deshpande et al. 2000; Fleischman and Valentine, 2003; Kwong et al. 2003) have concluded the differences between men's and women's ethical decision-making, some studies have determined that no differences exist between men's and women's ethical decision-making.

Individuals need to assess wrongdoing, and need to decide what to do if wrongdoing is present. So having information about level of moral reasoning of the possible whistle-blower might help to understand one's propensity to blow the whistle (Miceli et al. 2001). Researchers (i.e. Gundlach et al., 2003; Rocha and Kleiner, 2005) suggest that level of moral reasoning is one of the most important factors to understand one's tendency to blow the whistle, along with personality variables. Besides, many studies (Arnold and Ponemon, 1991; Brabeck, 1984; Chan and Leung, 2006; Miceli et al. 1991; Near and Miceli, 1985) claimed that moral reasoning influences an individual's decision-making process when deciding to blow the whistle. In addition, the ability to recognize and to correctly evaluate any ethical dilemma is important prerequisite to make the right ethical decisions (Miceli et al. ,2001). An ethical dilemma is a situation in which the person does not know how to act because of conflicting beliefs about what is axiologically required (Lurie and Albin, 2006). The researchers (McDevitt and Van Hise, 2002; Keenan, 2002; Tavakoli et al., 2003; and Near et al. 2004) evaluated materiality levels in ethical dilemmas in various studies in line with Rest's model. Besides, Reidenback and Robin (1990), Cohen et al. (1993, 2001), and Cruz et al. (2000) have used The Multi-dimensional Ethics Scale for examining ethical judgments in many studies, including the philosophical values such as justice, utilitarianism, relativism and egoism.

Rest's model has been particularly influential in terms of the actual decision process. The model identifies ethical decision-making process as involved in four steps: identifying the moral issue, making a moral judgment, establishing moral intent, and engaging in moral action (Rogojan, 2009; Woiceshyn, 2011). Most of the studies (i.e. McDevitt and Van Hise, 2002; Keenan, 2002; Tavakoli et al., 2003; and Near et al., 2004) validated this model and tested the impact of a wide variety of factors on the decision process, evaluating materiality levels in ethical dilemmas. Having used ethical dilemmas in their research, Brabeck (1984) and Dozier and Miceli (1985) suggest that an individual's ability to resolve or interpret an ethical dilemma is affected by his/her moral reasoning. Besides, Lysonsky and Gaidis (1991) suggest that the ethical sensitivity of students is comparable to real employees. Therefore, many studies have investigated students' moral reasoning levels and how these affect their ability to interpret ethical dilemmas (Arnold and Ponemon, 1991; Chan and Leung, 2006; Uddin and Gillett, 2002; and Welton et al. 1994). The results of these studies show that an individual's moral reasoning level or moral judgment affects their ethical behavior.

Rest's model (Woiceshyn, 2011) claims that engaging in moral action is the last step of decision-making process. In this step, the individual decides whether to report the wrongdoing s/he observed or not. An individual might blow the whistle in different ways. Park et al. (2008) proposed a typology of whistle-blowing based on three dimensions. Each dimension represents individual's choice for whistle-blowing formally or informally, internally, or externally, and identified or anonymously. Blowing the whistle formally means reporting wrongdoing in an institutional form. A whistle-blower reports such wrongdoing by pursuing formal organizational protocols or communication channels (Park et al. 2008). Blowing the whistle internally refers to reporting wrongdoing to a supervisor or someone else within the organization who can correct the wrongdoing. In contrast, blowing the whistle externally means reporting a wrongdoing to outside parties believed to have the power to correct it. Wrongdoings that are eventually reported externally are first reported internally (Miceli and Near, 1994; Vinten, 1996; Park et al. 2008). Lastly, identified whistle-blowing refers to an instance in which the individual reporting the wrongdoing uses his or her real name, or when information to identify whistle-blower is 
provided. However using a nickname, or giving no information about him/herself while blowing the whistle, means anonymous whistle-blowing (Park et al., 2008). Researchers have examined the relationship between culture and whistleblowing intentions comparing different cultures. For example, while Keenan (2002) found no significant difference between American and Indian managers in the likelihood of blowing the whistle, Tavakali et al (2003) found a significant difference between the U.S. and Croatian managers with respect to both individual and organizational tendencies to whistle blow. Park et al. (2008) found that there are significant variations related to nationality and cultural orientation among undergraduate students from South Korea, Turkey, and the U.K. Nayir and Herzig (2012) examined the relationship between value orientations of Turkish managers and their choices for particular whistle-blowing modes in Turkey.

\subsection{Verbal-Linguistic Intelligence vs. Mathematical - Logical Intelligence}

Gardner (2008) provides eight different potential pathways to learning in his multiple intelligences theory. Verbal-linguistic intelligence involves the knowledge which comes through language, through reading, writing, and speaking. People who have verbal-linguistic intelligence as a strong intelligence have highly developed skills for reading, speaking, and writing. On the other hand, 'mathematical-logical intelligence uses numbers, math, and logic to find and understand the various patterns that occur in our lives. People who have a logical-mathematical Intelligence as a strong intelligence tend to think more conceptually and abstractly and are often able to see patterns and relationships that others miss (http://www.multipleintelligencetheory.co.uk, http://www2.wmin.ac.uk).

\subsection{Examining Student Teachers}

Introductory courses serve as an excellent place to introduce the complexity of the role of teachers at schools for prospective teachers. These courses can examine several of the ethical dimensions of educational cases and students can evaluate the harmful consequences of the actions analyzed. Cohen et al. (2001) studied the differences in ethical decision-making between Canadian university entry-level and graduate business students and accounting professionals. Park et al. (2008) examined university students from South Korea, Turkey and the U.K in respect to different materiality levels implementing ethical scenarios through philosophical values. Liyanarachchi and Newdick, (2009) examined the effect of students' level of moral reasoning, on their intention to whistle blow in New Zealand. Mayhew and Murphy (2008) studied fourth-year students in the United States. Although the literature on whistle-blowing has grown over recent years, little research is available in Turkey on this issue. So the aim of this paper is to address whistle-blowing intentions of 1 stand last-year student teachers with respect to Gardner's (2008) verbal and mathematical intelligence, investigating their moral reasoning to blow the whistle. Students who were studying school teaching and English teaching were understood to have verbal intelligence, while those who were studying math and science teaching were understood to have mathematical intelligence. Rest's (Woiceshyn, 2011) four-component model that specifies four sequential steps an individual must take to incorporate the ethical dimension in a decision was used in the study. Since the level of moral reasoning is the one of the most important factors to understanding one's propensity to blow the whistle (Liyanarachchi, Newdick, 2009), students' reasoning for ethical evaluation needed to be examined in ethical dilemmas. In addition, since the ethical sensitivity of students is comparable to real employees (Lysonsky and Gaidis, 1991), student teachers were examined in the study. Further, since one of the research goals was to determine whether the respondents' intelligences (verbal or mathematical) were correlated with responses, these were included in the model. Thus students' underlying reasons for their ethical decision-making and their intention to blow whistle were examined through the following questions:

(1) Is there any difference between the $1^{\text {st }}$ and $4^{\text {th }}$ year students in terms of overall ethical awareness?;

(2) Is there any difference between the students who were supposed to have verbal intelligence and the students who were supposed to have mathematical intelligence in terms of overall ethical awareness?;

(3) Is there any difference between the $1^{\text {st }}$ and $4^{\text {th }}$ year students in terms of identifying reasons related to philosophical values as reasons for reporting wrongdoing?;

(4) Is there any difference between the students who were supposed to have verbal intelligence and the students who were supposed to have mathematical intelligence in terms of identifying reasons related to philosophical values as reasons for reporting wrongdoing?;

(5) Is there any significant difference between the 1 st and $4^{\text {th }}$ year students in terms of attitudes toward the ways in which a teacher might blow the whistle on wrongdoing in a school?; and 
(6) Is there any significant difference between the students who were supposed to have verbal intelligence and the students who were supposed to have mathematical intelligence in terms of attitudes toward the ways in which a teacher might blow the whistle on wrongdoing in a school?

\section{Research methodology}

\subsection{Participants}

335 first and fourth year students studying in the Faculty of Education of a large university in Turkey were chosen as sample for the study. The survey was administered to the students who were voluntary to participate it toward the end of the semester, and they provided anonymous responses. All students were provided with written information about the nature and purpose of the study. Of 335 responses, 291 were usable for the study. Hence, the sample of the study consisted of 162 first year students studying in the departments of elementary school teaching, elementary English language teaching, elementary mathematics teaching, and elementary science teaching, who had taken the 'Introduction to Education', and 'Educational Philosophy' courses, and $1294^{\text {th }}$ year students studying in the departments of elementary mathematics teaching, elementary science teaching, elementary English language teaching, and elementary school teaching, who had taken the 'School Management' course during the 2011-2012 academic year.

Fourth-year students were selected as sample, because to examine student teachers who were about to enter the teaching profession would result in a reasonable approximation to those teachers who are at the beginning of the teaching profession, and may encounter ethical dilemmas. Besides, students enrolled in the 'School Management' course had studied issues concerning school management and they had achieved understanding of school management due to their training implementations at schools. First-year students were selected as a sample because they had studied the 'Introduction to Education', and 'Educational Philosophy' courses, and they studied ethics in school management in these courses. Details of the sample can be found in Table 1.

Table 1. Sample Demographics

\begin{tabular}{|c|c|c|c|c|c|}
\hline \multirow{2}{*}{ Year } & \multirow{2}{*}{ Total } & \multicolumn{2}{|l|}{ Gender } & \multicolumn{2}{|l|}{ Departments } \\
\hline & & Female & Male & (School teaching/English) & (Math / science) \\
\hline 1 & 162 & $124(76 \%)$ & $38(24 \%)$ & $74(46 \%)$ & $88(54 \%)$ \\
\hline 4 & 129 & $98(76 \%)$ & $31(24 \%)$ & $70(54 \%)$ & $59(46 \%)$ \\
\hline
\end{tabular}

Of the $1^{\text {st }}$ year students, $76 \%$ were female, and $24 \%$ were male participants. While $46 \%$ of the $1^{\text {st }}$ year students were studying in social departments (school teaching, and English teaching), $54 \%$ were studying in science departments (math, and science teaching). In addition, of the $4^{\text {th }}$ year students, $76 \%$ were female while $24 \%$ were male participants. While 54\% were studying school teaching and English language teaching, $46 \%$ were studying mathematics and science teaching. Thus, of the 1 st-year students, $54 \%$ were understood to have mathematical intelligence and $46 \%$ were understood to have verbal intelligence of the $4^{\text {th }}$-year students, $46 \%$ students were understood to have mathematical intelligence and $54 \%$ were understood to have verbal intelligence.

\subsection{Instrument}

The author developed the questionnaire reviewing the literature. The questionnaire consisted of three scenarios with two parts of scales for each scenario. The first part was a modification of the Multi-dimensional Ethics Scale by Cohen et al. (1993, 2001), and it measured underlying philosophical reasons of the students. The second part was a modification of the scale, which was developed by Park et al. (2008), and measured attitudes toward the ways in which a teacher blows the whistle for each ethical scenario. Since Near et al. (2004) claimed that the type of wrongdoing affects the observers' choice to blow the whistle, the scenarios were chosen from newspapers according to the taxonomies suggested by Robinson and Bennett (1995) and Near et al. (2004). Stealing, sexual harassment, and violation cases were chosen because they are more obvious wrongdoings at organizations. After the discussion with real teachers as the cases were happening at schools, those cases were included in the questionnaire. Also personal information (gender, age, and departments) was asked at the beginning of the questionnaire. 
Three scenarios were constructed by the author surveying the literature and the newspapers related to schools (See Appendix A). Each of the scenarios consists of a short description of an ethical situation that the students might encounter in their professional careers at schools. The first subscale of the questions measured underlying philosophical reasons, and the second one examined students' attitudes toward the ways in which a teacher blows the whistle for each scenario. Cohen et al. $(1993,1996 ;$ 2001) developed the Multi-dimensional Ethics Scale (MES) claiming that Rest's four component model of moral decision-making recognizes the importance of moral reasoning in the decision-making process. So, MES was modified by the author in Turkish to measure students' ethical underlying reasons. The MES exposes a moral evaluation within the philosophical views of justice, utilitarianism, relativism and egoism (Cohen et al, 1996; 2001). The students' attitudes toward the various ways in which a teacher might report internally or externally, formally or informally, and identified or anonymously were measured by the scale developed by the author surveying the literature (Park et al., 2008) (See Table 3).

Since it is assumed that ethical decision-making skills of the first-year students were not as mature as $4^{\text {th }}$-year students, three obviously unethical cases were constructed by the author as the potential events that they might encounter in their professional careers at schools. To get answers for the first and the second questions of the study one item (Item5. 'It is ethical') was included as an overall measure of ethical awareness of the participants in the first scale of the questionnaire. Respondents were asked to indicate how much they agreed or disagreed with statements related to the scenarios on a seven-point Likert scale, ranging from 'very likely ethical' (1) to 'absolutely unethical' (7) for each scenario (See Appendix B). To get answers for the $3^{\text {rd }}$ and the $4^{\text {th }}$ questions of the study MES were used. The scenarios and the subscales were revised for the first-class students, and the subscale items were modified according to their comprehensions after the piloting. The items involved in the MES were reduced during the piloting. Therefore four items (Items1-4) were included as underlying philosophical reasons with four ethical theories in the first subscale of the instrument: justice (the idea of fairness), relativism (the action is considered acceptable culturally), utilitarianism (the action leads to maximum benefits while minimizing harm), and egoism (the action is based on self-promoting for the school principal) (Cohen, et al, 1996; 2001). The participants were asked to evaluate scenarios with the underlying philosophical reasons through justice, utilitarianism, relativism and egoism on a seven-point Likert scale, ranging from 'very likely' (1) 'to never' (7) in the first subscale of the instrument. The Cronbach's alpha values of all scenarios' first subscales (modified MES) were above 0.60 , and so the reliability of the subscales is acceptable for statistical analysis (See Table 2) (Buyukozturk, 2002).

Table 2. Item loads and Cronbach's alpha values of the ethical evaluation with philosophical reasons

\begin{tabular}{|llllll|}
\hline & Item & Scenario1 & Scenario2 & Scenario3 & Cronbach's alpha \\
\hline Ethical evaluation & It is ethical & .68 & .66 & .78 & .833 \\
Justice & Principals' behavior is just & .42 & .48 & .58 & .674 \\
Relativism & Culturally acceptable & .67 & .60 & .72 & .796 \\
Egoism & Self-promoting for the actor & .54 & .49 & .67 & .737 \\
Utilitarianism & Produces the greatest utility & .46 & .59 & .64 & .735 \\
\hline
\end{tabular}

To get answers for the $5^{\text {th }}$ and the $6^{\text {th }}$ questions of the study four items were included at the end of the each scenario, modified by Park et al. (2008), as the second subscale. Each item was rated on a five-point scale, ranging from 'strongly disapprove' (1) to 'strongly approve' (5). The Cronbach's alpha value of the items of all the subscales was above 0.80 , and so the reliability of the scales is acceptable for statistical analysis (See Table 3).

Table 3. The Second Subscale Items: Attitudes to different types of whistleblowing

\begin{tabular}{|c|c|c|}
\hline & Item & Cronbach's alpha \\
\hline Internal & $\begin{array}{l}\text { Report the wrongdoing to the other teachers or staff within the school } \\
\text { Report it to deputy principal }\end{array}$ & .896 \\
\hline External & Let inspector know about it when s/he comes to school for inspection & .904 \\
\hline
\end{tabular}




\begin{tabular}{|c|c|c|}
\hline & $\begin{array}{l}\text { Let provincial management know about it } \\
\text { Let the other schools' staff know about it } \\
\text { Let parents know about it } \\
\text { Let press know about it }\end{array}$ & \\
\hline Identified & $\begin{array}{l}\text { Reports it by using my real name. } \\
\text { Reports the wrongdoing by giving detailed information about myself }\end{array}$ & .919 \\
\hline Anonymously & $\begin{array}{l}\text { Reports it using an assumed name } \\
\text { Reports the wrongdoing but don't give any information about myself }\end{array}$ & .893 \\
\hline Formal & $\begin{array}{l}\text { Use official channels to report it. } \\
\text { Reports it by means of procedures already in place }\end{array}$ & .835 \\
\hline Informal & $\begin{array}{l}\text { Informally report it to close associates who could correct it } \\
\text { Informally report it to someone s/he trusts who is in charge of correcting it }\end{array}$ & .921 \\
\hline
\end{tabular}

\section{Findings and discussion}

\subsection{Ethical Orientation}

To get answer for the first question t-test results were examined (See .Table 4).

Table 4. T-test results for the overall ethical evaluation of the students

\begin{tabular}{|c|c|c|c|c|c|c|c|}
\hline It is unethical & Year & $\mathrm{N}$ & Mean & Std. Dev. & $t$ & df & Sig.(2-tailed) \\
\hline \multirow{2}{*}{ Scenario 1} & 1 & 162 & 6.66 & 1.29 & \multirow{2}{*}{0.56} & \multirow{2}{*}{288} & .570 \\
\hline & 4 & 128 & 6.74 & 0.86 & & & \\
\hline \multirow{2}{*}{ Scenario 2} & 1 & 161 & 6.71 & 1.09 & \multirow{2}{*}{0.74} & \multirow{2}{*}{288} & .457 \\
\hline & 4 & 129 & 6.62 & 1.03 & & & \\
\hline \multirow{2}{*}{ Scenario 3} & 1 & 160 & 6.79 & 1.01 & \multirow{2}{*}{1.78} & \multirow{2}{*}{287} & .076 \\
\hline & 4 & 129 & 6.96 & 0.36 & & & \\
\hline
\end{tabular}

As Table 4 shows, there is not any difference in ethical evaluation between the students in terms of overall ethical awareness. Meanwhile, the mean scores indicate that while $4^{\text {th }}$-year students seem to be more aware of ethicality for the first and the third scenarios, they seem to be less aware for the second scenario than the 1 st year students. So, the $1^{\text {st }}$ year students might be regarded to be more aware of ethically situations related to violations than the $4^{\text {th }}$ year students. These results are in line with Mayhew and Murphy (2008), who concluded that that ethics education can impact ethical behavior, but ethics education does not necessarily result in internalized ethical values.

To get answer for the second question t-test results were analyzed (See Table 5).

Table 5. T-test results for the overall ethical evaluation of the students

\begin{tabular}{|c|c|c|c|c|c|c|c|}
\hline It is unethical & Style & $\mathrm{N}$ & Mean & Std. Dev. & $t$ & $\mathrm{df}$ & Sig.(2-tailed) \\
\hline \multirow{2}{*}{ Scenario 1} & Verbal & 143 & 6.72 & 1.10 & \multirow{2}{*}{0.30} & \multirow{2}{*}{288} & .762 \\
\hline & mathematical & 147 & 6.68 & 1.13 & & & \\
\hline \multirow{2}{*}{ Scenario 2} & Verbal & 143 & 6.84 & 0.87 & \multirow{2}{*}{2.76} & \multirow{2}{*}{288} & $.006^{*}$ \\
\hline & mathematical & 147 & 6.50 & 1.20 & & & \\
\hline \multirow{2}{*}{ Scenario 3} & Verbal & 144 & 6.86 & 0.86 & \multirow{2}{*}{0.15} & \multirow{2}{*}{287} & .875 \\
\hline & mathematical & 145 & 6.87 & 0.72 & & & \\
\hline
\end{tabular}


As Table 5 shows there is significant difference in ethical evaluation between the students in terms of overall ethical awareness at scenario 2. Mean scores show that the students with verbal intelligence seem to be more aware ethically than the others in scenario 2.

To get answer for the third question descriptive statistics were used firstly (See Table 6)

Table 6. Means of the Justice, Utilitarianism, Relativism and Egoism of Each Scenario

\begin{tabular}{|lllllll|}
\hline & Year & It is unethical & Justice & Relativism & Egoism & Utilitarianism \\
\hline \multirow{2}{*}{ Scenario 1 } & 1 & 6.66 & 6.73 & 6.68 & 2.84 & 5.88 \\
& 4 & 6.74 & 6.75 & 6.65 & 2.80 & 6.27 \\
Scenario 2 & 1 & 6.71 & 6.72 & 6.61 & 5.88 & 6.43 \\
& 4 & 6.62 & 6.65 & 6.37 & 4.92 & 6.16 \\
Scenario 3 & 1 & 6.79 & 6.78 & 6.78 & 4.67 & 6.38 \\
& 4 & 6.96 & 6.84 & 6.96 & 5.27 & 6.48 \\
\hline
\end{tabular}

The overall ethical evaluation of each scenario is modeled as a linear weighting of each of the four awareness measures. The regression coefficients of overall evaluation on the four measures of awareness estimate this weighting, and the test was done for differences in the regression coefficients between groups to test for differences in ethical orientation in the two groups. Since Trevino (1986) suggests that ethical evaluations are issue-specific, each scenario was examined separately. Therefore the overall evaluation score was regressed on the four awareness measures in each of the two groups as follows: Evaluation $=a+b 1$ (justice) $i+b 2$ (relativism) $i+b 3($ egoism) $i+b 4($ utilitarianism) $i+$ ei where subscript $i$ refers to an individual. The regression coefficients and their significance for the students are shown in Table 7.

Table 7. Regression Coefficients of Ethical Evaluation on Four Dimensions for Three Scenarios for the students

\begin{tabular}{|c|c|c|c|c|c|}
\hline & & $1^{\text {st }}$ yea & & $4^{\text {th }}$ yea & \\
\hline & Scenarıo & $\beta_{1}$ & Sig. & $\beta_{2}$ & Sig. \\
\hline & 1 & .153 & $.013^{\star *}$ & .654 & $.000^{*}$ \\
\hline Justice & 2 & .246 & $.000^{*}$ & .498 & $.000^{*}$ \\
\hline & 3 & .547 & $.000^{*}$ & .000 & . \\
\hline & 1 & .561 & $.000^{*}$ & .234 & $.005^{* \star}$ \\
\hline Relativism & 2 & .579 & $.000^{*}$ & .209 & $.027^{\star \star}$ \\
\hline & 3 & .445 & $.000^{*}$ & 1.000 & . \\
\hline & 1 & -.131 & $.006^{\star *}$ & .012 & .797 \\
\hline Egoism & 2 & -.004 & .920 & .001 & .990 \\
\hline & 3 & -.007 & .521 & .000 & . \\
\hline & 1 & .227 & $.000^{*}$ & .043 & .367 \\
\hline Utilitarianism & 2 & .183 & $.000^{*}$ & .241 & $.000^{*}$ \\
\hline & 3 & .003 & .802 & .000 & . \\
\hline & 1 & $66 \%$ & & $78 \%$ & \\
\hline Adjusted R2 & 2 & $82 \%$ & & $64 \%$ & \\
\hline & 3 & $99 \%$ & & $100 \%$ & \\
\hline
\end{tabular}

${ }^{*} p<.001,{ }^{* *} p<.05$ 
Since the $4^{\text {th }}$ year students marked 7 'absolutely unethical' mostly, the correlation between justice, egoism and utilitarianism and ethical awareness emerged as zero in scenario 3 . Additionally, the beta $\left(\beta_{2}\right)$ weight for relativism was 1.00 for scenario 3. Near et al. (2004) claim that type of wrongdoing significantly affect observers' chose to blow the whistle. Therefore the students seem to have considered scenario 3 as an absolutely unethical case. Table 7 indicates that justice has the strongest influence in all scenarios for the $4^{\text {th }}$ year students, while relativism and justice have strongest influence in all scenarios for the $1^{\text {st }}$ year students. In addition, scenario 1 elicited the most complex reasoning, because all ethical criteria affected the $1^{\text {st }}$ year students during ethical decision-making in that scenario. Similarly, scenario 2 elicited complex reasoning, because all ethical criteria affected the $1^{\text {st }}$ year students during ethical decisionmaking in that scenario. Therefore, the $1^{\text {st }}$ year students seem to evaluate ethical scenarios based on justice, relativism, and utilitarianism. In addition, the $4^{\text {th }}$ year students' judgment based on justice was strong in their ethical decision-making in 1 and 2 scenarios. These results are consistent with studies conducted by Cohen et al. $(1993,1996 ; 2001)$ who found that egoism is not a significant underlying influence on ethical decisions, and Cruz et al. (2000) who found that justice, relativism, and utilitarianism influence ethical decisions. Surprisingly, relativism itself explains $4^{\text {th }}$ students' ethical decision-making for the scenario 3.

To get answer for the $4^{\text {th }}$ question descriptive statistics were used firstly (See Table 8)

Table 8. Means of the ethical values of Each Scenario for the students

\begin{tabular}{|lllllll|}
\hline & Style & It is ethical & Justice & Relativism & Egoism & Utilitarianism \\
\hline \multirow{2}{*}{ Scenario 1 } & Verbal & 6.72 & 6.75 & 6.65 & 3.24 & 6.16 \\
& mathematical & 6.68 & 6.72 & 6.62 & 3.60 & 5.95 \\
\multirow{2}{*}{ Scenario 2 } & Verbal & 6.84 & 6.86 & 6.69 & 5.64 & 6.51 \\
& mathematical & 6.50 & 6.52 & 6.32 & 5.27 & 6.12 \\
\multirow{2}{*}{ Scenario 3 } & Verbal & 6.86 & 6.84 & 6.68 & 4.92 & 6.46 \\
& mathematical & 6.87 & 6.77 & 6.86 & 4.95 & 6.40 \\
\hline
\end{tabular}

The overall evaluation score was regressed on the four awareness measures in each of the two groups as follows: Evaluation $i=\mathrm{a}+\mathrm{b} 1$ (justice) $i+\mathrm{b} 2$ (relativism) $i+\mathrm{b} 3$ (egoism) $i+\mathrm{b} 4$ (utilitarianism) $i+$ ei where subscript $i$ refers to an individual. The regression coefficients and their significance for the students with verbal intelligence and the students with mathematical intelligence are shown in Table 9. 
Table 9. Regression Coefficients of Ethical Evaluation on Four Dimensions for Three Scenarios for the students

\begin{tabular}{|c|c|c|c|c|c|}
\hline & \multirow{2}{*}{ Scenario } & \multicolumn{2}{|l|}{ verbal } & \multicolumn{2}{|c|}{ mathematical } \\
\hline & & $\beta_{1}$ & Sig. & $\beta_{2}$ & Sig. \\
\hline & 1 & .093 & .111 & .682 & $.000^{*}$ \\
\hline \multirow[t]{3}{*}{ Justice } & 2 & .290 & $.000^{*}$ & .486 & $.000^{*}$ \\
\hline & 3 & -.003 & .908 & .033 & .065 \\
\hline & 1 & .639 & $.000^{*}$ & .132 & $.047^{* *}$ \\
\hline \multirow[t]{3}{*}{ Relativism } & 2 & .442 & $.000^{*}$ & .286 & $.000^{*}$ \\
\hline & 3 & 1.000 & $.000^{*}$ & .959 & $.000^{*}$ \\
\hline & 1 & -.084 & .105 & -.055 & .146 \\
\hline \multirow[t]{3}{*}{ Egoism } & 2 & .058 & .224 & -.023 & .592 \\
\hline & 3 & -.003 & .745 & -.002 & .839 \\
\hline & 1 & .205 & $.001^{* *}$ & .131 & $.001^{* *}$ \\
\hline \multirow[t]{3}{*}{ Utilitarianism } & 2 & .243 & $.000^{*}$ & .199 & $.000^{*}$ \\
\hline & 3 & -.003 & .796 & .006 & .638 \\
\hline & 1 & $67 \%$ & & $71 \%$ & \\
\hline \multirow[t]{2}{*}{ Adjusted R² } & 2 & $73 \%$ & & $69 \%$ & \\
\hline & 3 & $99 \%$ & & $98 \%$ & \\
\hline
\end{tabular}

${ }^{*} \mathrm{p}<.001,{ }^{* *} \mathrm{p}<.05$

As Table 9 demonstrates, relativism had the strongest influence in all scenarios for the two groups' responses. Justice had a strong effect in all scenarios for the students with mathematical intelligence while it had an effect only in scenario 2 for the other group. In addition, utilitarianism had a strong effect in scenarios 1 and 2 for both groups. These results are consistent with studies conducted by Cohen et al. $(1993,1996)$, and Cruz et al. $(2000)$ who found that these constructs influence ethical decisions described in their scenarios. Further, the results show that egoism has no effect on the students' ethical decision-making in all scenarios. The finding related to egoism is consisted with Cohen et al. (1993, 1996) who found that egoism is not a significant underlying influence on ethical decisions.

To get answer for the $5^{\text {th }}$ question a t-test was used to explore the differences in students' attitudes on the various dimensions of reporting wrongdoing (Table 10). 
Table 10. T-test results for of attitudes toward whistleblowing for the students

\begin{tabular}{|llllllll|}
\hline Type of reporting & Year & $\mathrm{N}$ & Mean & Std. Dev. & $\mathrm{t}$ & $\mathrm{df}$ & Sig.(2-tailed) \\
\hline \multirow{2}{*}{ Internal } & 1 & 153 & 4.01 & 0.95 & 4.50 & 275 & $.000^{*}$ \\
& 4 & 124 & 3.46 & 1.05 & & & \\
External & 1 & 145 & 3.29 & 0.91 & 5.02 & 259 & $.000^{*}$ \\
Identified & 4 & 116 & 2.76 & 0.72 & & & \\
& 1 & 142 & 3.61 & 1.14 & 2.05 & 265 & $.041^{* *}$ \\
Anonymous & 4 & 125 & 3.32 & 1.17 & & & .960 \\
Formal & 1 & 144 & 2.00 & 0.98 & 0.50 & 267 & .460 \\
& 4 & 125 & 2.00 & 0.88 & & & \\
Informal & 1 & 137 & 3.64 & 1.02 & -.740 & 259 & .066 \\
& 4 & 124 & 3.73 & 0.92 & & & \\
\hline
\end{tabular}

${ }^{*} p<01{ }^{* *} p<.05$

Table 10 demonstrates that there are significant differences between the students' preferences toward internal, external, and identified reporting. The results show that 1 st year students' intentions for both internal $\left(t_{275}=4.50, p<.01\right)$ and external $\left(t_{259}=5.02, p<.01\right)$ reporting are higher than the $4^{\text {th }}$ year ones. Similarly, 1 st year students' intentions for identified reporting are higher than the $4^{\text {th }}$ year students $\left(t_{265}=2.05, p<.05\right)$. Besides, both 1 st and $4^{\text {th }}$ year students show a marked preference for internal over external and identified over anonymous ( $\left.t_{267}=0.50, p<.05\right)$ reporting. The differences in means between internal $\left(t_{275}=4.50, p<.05\right)$, external $\left(t_{259}=5.02, p<.05\right)$, and identified $\left(t_{265}=2.05, p<.05\right)$ are substantial. However, means of intentions for anonymous reporting do not make any difference for the groups. Thus $1^{\text {st }}$ year students seem to prefer internal, external, and identified reporting more than the $4^{\text {th }}$ year ones prefer. While different studies related to whistle-blowing intentions have been conducted, the students' intentions for whistle-blowing were not examined in literature. Thus these findings could not be compared with the other studies.

To get answer for the $6^{\text {th }}$ question t-test was used to explore the differences in students' attitudes on the various dimensions of reporting wrongdoing (Table 11).

Table 11. T-test results for of attitudes toward whistleblowing for the students

\begin{tabular}{|c|c|c|c|c|c|c|c|}
\hline Type of reporting & & $\mathrm{N}$ & Mean & Std. Dev. & $t$ & df & Sig.(2-tailed) \\
\hline \multirow{2}{*}{ Internal } & Verbal & 138 & 3.87 & 1.04 & 1.73 & 275 & .084 \\
\hline & mathematical & 139 & 3.66 & 1.01 & & & \\
\hline \multirow{2}{*}{ External } & Verbal & 125 & 3.11 & 0.90 & 0.90 & 259 & .364 \\
\hline & mathematical & 136 & 3.01 & 0.85 & & & \\
\hline \multirow{2}{*}{ Identified } & Verbal & 129 & 3.57 & 1.18 & 1.25 & 265 & .209 \\
\hline & mathematical & 138 & 3.39 & 1.14 & & & \\
\hline \multirow{2}{*}{ Anonymous } & Verbal & 133 & 1.94 & 0.89 & -1.07 & 267 & .285 \\
\hline & mathematical & 136 & 2.06 & 0.98 & & & \\
\hline \multirow{2}{*}{ Formal } & Verbal & 129 & 3.72 & 0.99 & 0.57 & 259 & .566 \\
\hline & mathematical & 132 & 3.65 & 0.96 & & & \\
\hline \multirow{2}{*}{ Informal } & Verbal & 137 & 4.09 & 0.96 & 0.12 & 278 & .897 \\
\hline & mathematical & 143 & 4.08 & 0.93 & & & \\
\hline
\end{tabular}


As Table 11 indicates, there is not any significant difference between the intentions of students toward reporting. Although there is not any significant difference between the students, the means of the students with verbal intelligence are higher than the others, which implies that students with mathematical intelligence seem to prefer anonymous reporting more than the other ones.

\section{Concluding remarks}

Before examining the results in more detail, some of the methodological limitations should be acknowledged. There might be drawbacks in the use of student participants, in terms of their generalizability to the wider population. Besides, the use of self-reported attitudes means that students' responses might merely reflect prevailing social norms, or be subject to social desirability effects (Park et al., 2008). In addition, the samples in this study may not even be representative of the population of university students in Turkey. Further, the scenarios to which the students were asked to respond are very specific, and it may be that their responses in part reflect their attitudes toward that particular form of wrongdoing. Despite this limitation, the study offers a number of important insights.

The purpose of this study was to examine whether there are significant differences between $1^{\text {st }}$ and the $4^{\text {th }}$ year student teachers' attitudes toward whistle-blowing with respect to having verbal or mathematical intelligence. So this study contributes to the existing whistle-blower literature in this way. Results showed that there is not any difference in ethical evaluation between $1^{\text {st }}$ and the $4^{\text {th }}$ year students in terms of overall ethical awareness. On the other hand, the students with verbal intelligence seem to be more aware ethically than the other group in scenario 2 . These results are in line with the Mayhew and Murphy (2008). The 1 st year students seem to evaluate scenarios based on justice, relativism, and utilitarianism, while the other group used justice strongly as the basis for their reasoning in their ethical decisionmaking processes in the 1 st and 2 nd scenarios. Surprisingly, relativism itself seemed to express whistle-blowing intentions of the $4^{\text {th }}$ year students while the other values had no effect on it in scenario 3 . Similarly, relativism had the strongest influence for the responses of the students with verbal and mathematical intelligence in all scenarios. Additionally, justice had the strongest influence in all scenarios for the $4^{\text {th }}$ year students, while relativism and justice had the strongest influence in all scenarios for the $1^{\text {st }}$ year students. On the other hand, justice had a strong effect in all scenarios for the students with mathematical intelligence while it had a noticeable effect only in scenario 2 for the students with verbal intelligence. In addition, utilitarianism had a strong effect in scenarios 1 and 2 for both students with verbal and mathematical intelligence. Further, the results show that egoism had no effect on the students' ethical decision-making in all scenarios, regardless of intelligence type. These results are in line with Cruz et al. (2000), and Hudson and Miller (2005). In addition, the study results are consistent with the results of studies by Cohen et al. (1993, 1996, 2001).

The results revealed that the $1^{\text {st }}$ year students' intentions for internal, external, and identified reporting are higher than the $4^{\text {th }}$ year ones. Besides, both 1 st and $4^{\text {th }}$ year students show a marked preference for internal over external and identified over anonymous reporting. The differences in mean scores between internal, external, and identified reporting are substantial. The $1^{\text {st }}$ year students seem to prefer internal, external, and identified reporting more than the $4^{\text {th }}$ year ones prefer. These findings are in line with the results shown by Park et al., (2008). In addition, the results related to the students' intelligence styles show that only preferring internal reporting made a significant difference between the students. The students with verbal intelligence prefer internal reporting more than those with mathematical intelligence. It is concluded that having mathematical intelligence played a very small role in students' intentions for external, identified, anonymous, formal and informal reporting. While there is not any significant difference between the students' intentions toward reporting according to the mathematical intelligence; the students who have verbal intelligence prefer internal reporting more than the other group.

I hope this study will bring attention to the darker side of organizational behavior by examining whistle-blowing with level of studying teaching and intelligence type. While lots of studies have been conducted to explain intentions for reporting wrongdoing of a whistle-blower no one examined any relation between intelligence type and whistle-blowing. So this paper is concluded with a consideration of directions for future research. There are good grounds for assuming that studies replicating the present research design could be worthwhile.

\section{References}

Arnold, D. F. and Ponemon, L. A. (1991). Internal Auditors Perceptions of Whistle Blowing and the Influence of Moral Reasoning: An Experiment. Auditing: A Journal of Practice and Theory, 10, 1-15.

Brabeck, M. M. (1984). Ethical Characteristics of Whistle-Blowers. Journal of Research in Personality, 18, 41-53. 
Büyüköztürk, Ş. (2004). Data analysis for Social sciences hand book, $4^{\text {th }}$ Edition. Ankara: Pegem Press.

Chan, S. Y. and Leung, P. (2006). The Effects of Accounting Students Ethical Reasoning and Personal Factors on Their Ethical Sensitivity. Managerial Auditing Journal, 21, 436-457. doi:10.1108/02686900610661432.

Cohen, J.R., Pant, L.,W., and Sharp, D.J. (1993). Culture-Based Ethical Conflicts Confronting Multinational Accounting Firms. Accounting Horizon, 7 (3), 1-13.

Cohen, J. R., Pant, L., W., and Sharp, D. J. (1996). Measuring the Ethical Awareness and Ethical Orientation of Canadian Auditors. Behavioral Research in Accounting 8, 98-119.

Cohen, J.R., Pant, L.W., Sharp, D.J. (2001). An Experimentation of Differences in Ethical Decision-Making Between Canadian Business Students and Accounting Professionals. Journal of Business Ethics, 30, 319-336.

Cruz, C. A., Shafer, W.E. and Strawser, J. R. (2000). A Multidimensional Analysis of Tax Practitioner's Ethical Judgments. Journal of Business Ethics, 24 (3), 223-245

Dawson, L. M. (1997). Ethical Differences between Men and Women in the Sales Profession. Journal of Business Ethics, 16, 11431152.

Dawson, S. (2000). Whistleblowing: A Broad Definition and Some Issues for Australia, (Working paper by Victoria University of Technology). Retriewed http://www.bmartin.cc/dissent/documents/Dawson.html.

Deshpande, S. P. (1997). Managers' Perception of Proper Ethical Conduct: The Effect of Sex, Age, and Level of Education. Journal of Business Ethics, 16 (1), 79-85.

Deshpande, S. P., J. Joseph and Maximov. V. V. (2000). Perceptions of Proper Ethical Conduct of Male and Female Russian Managers. Journal of Business Ethics, 24 (2), 179-183.

Dozier, J. B. ve Miceli, M.P. (1985). Potential Predictors of Whistle-Blowing: A Prosocial Behavior Perspective. Academy of Management Review, $10(4), 823-836$.

Elliston, F. A. (1982). Civil Disobedience and Whistleblowing: A Comparative Appraisal of Two Forms of Dissent. Journal of Business Ethics, 1, 167-177.

Fleischman, G. and Valentine, S. (2003). Professionals'Tax Liability Assessments and Ethical Evaluations in an Equitable Relief Innocent Spouse Case. Journal of Business Ethics, 42, 27-44.

Franke, G. R., D. F. Crown and Spake, D. F. (1997). Gender Differences in Ethical Perceptions of Business Practices: A Social Role Theory Perspective. Journal of Applied Psychology, 82, 920-934

Gardner, H. (2008). What are Multiple Intelligences? Retriewed www.multipleintelligencetheory.co.uk

Gundlach, M. J., Douglas, S. C. and Martinko, M. J. (2003). The Decision to Blow theWhistle: A Social Information Processing Framework. Academy of Management Review, 28 (1), 107-123.

Hudson and Miller (2005) Ethical Orientation and Awareness of Tourism Students. Journal of Business Ethics, 62, 383-396 Doi:10.1007/s10551-005-0850-8

Jubb, P.B., (1999). Whistleblowing: A Restrictive Definition and Interpretation. Journal of Business Ethics, 21 (1), 77-94

Keenan, J.P., (2002). Comparing Indian and American Managers on Whistleblowing. Employee Responsibilities and Rights Journal, 14, 79-89.

Kwong, K. K., Yau, O. H. M. Lee, J. S. Y., Sin, L. Y. M. and, Tse, A. C. B. (2003). The Effects of Attitudinal and Demographic Factors on Intention to Buy Pirated CDs: The Case of Chinese Consumers. Journal of Business Ethics, 47, 223-235

Liyanarachchi, G., Newdick, C. (2009). The Impact of Moral Reasoning and Retaliation on Whistle-Blowing: New Zealand Evidence. Journal of Business Ethics, 89, 37-57.

Lurie, Y. and Albin, R. (2006). Moral Dilemmas in Business Ethics: From Decision Procedures to Edifying Perspectives. Journal of Business Ethics, 71, 195-207 Doi: 10.1007/s10551-006-9134-1

Mayhew, B.W. and Murphy, P.R. (2008). The Impact of Ethics Education on Reporting Behavior. Journal of Business Ethics, 86, 397416, Doi:10.1007/s10551-008-9854-5

McDevitt, R. and Van Hise, J. (2002). Influences in Ethical Dilemmas of Increasing Intensity. Journal of Business Ethics, 40 (3), $261-274$.

Miceli, M. P. and Near, J. P. (1985). Characteristics of Organizational Climate and Perceived Wrongdoing Associated with Whistleblowing Decisions. Personnel Psychology, 38 (3), 525-544.

Miceli, M. P. Near, J. P., Schwenk, C. R. (1991). Who Blows the Whistle and Why? Industrial and Labor Relations Review, 45 (1), $113-$ 130.

Miceli, M. P., Near, J. P. (1994). Relationships Among Value Congruence, Perceived Victimization, and Retaliation Against Whistleblowers: The Case of Internal Auditors'. J. Management, 20, 773-794.

Miceli, M. P., Rehg, M., Near, J. P. and Ryan, K. C. (1999). Can Laws Protect Whistle-Blowers? Results of a Naturally Occurring Field Experiment. Work and Occupations, 26, 129-151.

Miceli, M. P. Scotter, J. R. V., Near, J.P., and Rehg, M.T. (2001). Individual Differences and Whistle-blowing. Academy of Management Proceedings. 1-6.

Nayir, D. Z., Herzig, C. (2012). Value Orientations as Determinants of Preference for External and Anonymous Whistleblowing. J Bus Ethics, 107, 197-213, Doi: 10.1007/s10551-011-1033-4

Near, J.P. ve Miceli, M.P. (1985). Organizational Dissidence: The Case of Whistle-Blowing. Journal of Business Ethics, 4, (1), 1-16

Near, J. P., Dworkin, T. M., Miceli, M.P. (1993). Explaining the Whistleblowing Process: Suggestions from Power Theory and Justice Theory. Organization Science, 4 (3).

Near, J.P., Rehg, M.T., Scotter, J.R.V., Miceli, M.P. (2004). Does type of wrongdoing affect the whistleblowing process? Business Ethics Quarterly, 14 ( 2), 219-242 
Park, H., Blenkinsopp, J., Oktem, M. K., Omurgonulsen, U. (2008). Cultural Orientation and Attitudes Toward Different Forms of Whistleblowing: A Comparison of South Korea, Turkey, and the U.K. Journal of Business Ethics, 82, 929-939.

Reidenbach, R. and. Robin, D. (1990). Toward the development of a multidimensional scale for improving evaluations of business ethics. Journal of Business Ethics, 9, 639-653.

Robinson, S. L., and Bennett, R. J. (1995) A typology of deviant workplace behaviors: A multidimensional scaling study. Academy of Management Journal, 38, 555-572.

Rocha, E. and Kleiner, B. H. (2005). To Blow or Not to Blow the Whistle? That is the Question. Management Research News, 28 (11/12), 80-87. doi:10.1108/01409170510785264

Rogojan, P. (2009). Deviant Workplace Behavior in Organizations: Antecedents, Influences, and Remedies. Master Thesis. Retrieved from :http://othes.univie.ac.at/

Tavakoli, A. A., Keenan, J.P., Crnjak-Karanovic, B. (2003). Culture and whistleblowing an empirical study of Croatian and United States managers utilizing Hofstede's cultural dimensions. Journal of Business Ethics, 43 (1-2), 49.

Uddin, N. and Gillett, P. R. (2002). The Effects of Moral Reasoning and Self-Monitoring on CFO Intention to Report Fraudulently on Financial Statements. Accounting Organizations and Society, 40 (1), 41-51.

Vinten, G. (1996). Whistleblowing in the health-related professions. The Indian Journal of Medical Ethics. Retriewed website:: http://www.issuesinmedicalethics.org

Welton, R. E., J. R. Davis and LaGrone, M. (1994). Promoting the Moral Development of Accounting Graduate Students: An Instructional Design and Assessment. Accounting Education International Journal, 3 (1), 35-50.

Woiceshyn, J. (2011). A Model for Ethical Decision Making in Business: Reasoning, Intuition, and Rational Moral Principles. J Bus Ethics, 104, 311-323. Doi: 10.1007/s10551-011-0910-1

http://www2.wmin.ac.uk

\section{Appendix A: Scenarios}

You are working at a school as a teacher.

1. You witness that the school principle purchases a Xerox machine using the money that he has gathered from parents for that. Firm gives a laptop as a promotion to the school principle. And you witness him taking the laptop to his home

2. Four boy students disturb girl students at the school garden. The school principle calls the boy students to his room, and beats them without listening them. Further he threats them to keep their mouth shut.

3. You realized that school principle treats women teachers recklessly. He frequently calls some women teachers to his room. A day you witness that he abuses sexually one of the woman teachers.

Appendix B: Questions Related to Philosophical Values (Modified MES - Subscale1)

\begin{tabular}{llllllllll}
\hline & & 1 & 2 & 3 & 4 & 5 & 6 & 7 & \\
\hline 1 & Just & & & & & & & Unjust \\
2 & Culturally acceptable & & & & & & Culturally unacceptable \\
3 & Self-promoting for the actor & & & & & & Not self-promoting for the actor \\
4 & Produces the greatest utility & & & & & & Produces the least utility \\
5 & The action described above is ethical & & & & & & & The action described above is unethical \\
\hline
\end{tabular}


